\title{
Scale-dependent segregation of seeders and resprouters in cork oak (Quercus suber) forests
}

\author{
M. Coca ${ }^{1 *}$ and J.G. Pausas ${ }^{2}$ \\ ${ }^{1}$ Área de Ecología/RNM 311-Ecología y Medio Ambiente. Departamento de Biología Ambiental y \\ Salud Pública. Facultad de Ciencias Experimentales. Universidad de Huelva. Campus El Carmen, \\ ES-21071 Huelva, Spain and ${ }^{2}$ Centro de Investigaciones sobre Desertificación (CIDE, CSIC), \\ Apartado Oficial, ES-46470 Albal, Valencia, Spain \\ *For correspondence. E-mail mcocap@gmail.com
}

\begin{abstract}
Recent studies showed that disturbances and water availability determine the richness among plants with different post-fire strategies of Mediterranean-type ecosystems. The aim of this study was to determine whether or not the scale of analysis has an influence on the effects of these factors and, therefore, on the segregation of the dominant post-fire strategies, obligate seeders and obligate resprouters, and facultative species.
\end{abstract}

We recorded all woody species and geographical features on $94\left(75 \mathrm{~m}^{2}\right)$ plots of cork oak woodlands in the southern Iberian Peninsula. For each regenerative type (resprouters, seeders and species with both traits - facultative species), we tested the relationship between the number of species and the predictors using a generalised linear mixed model. The fixed predictor considered at the large scale was altitude, and fixed predictors considered at the local scale were aspect (north/south) and disturbance (fire and clearing by heavy machinery; yes/no). The random predictor was the factor of site. When this factor did not have significant effect for some regenerative types, these relationships was tested using a generalised linear model.

Resprouting species were most represented at lower altitudes and in undisturbed sites, while seeders were also at lower altitudes but mostly on south-facing slopes, especially south-facing disturbed sites. For facultative species, site is the most important variable. The proportion of seeders from the total species is not related to altitude, but it is related to disturbance and aspect. These results suggest that there is no segregation of the richness of seeders and resprouters at the large scale (altitudinal gradient). Differences appeared at the local scale (aspect and disturbance). Key words: post-fire strategies, disturbance, moisture regime, Mediterranean vegetation, cork oak forests.

\section{Introduction}

Cork oak forests are an emblematic Mediterranean ecosystem distributed throughout the western Mediterranean Basin (Aronson et al. 2009). They have been used by humans during millennia to obtain acorns (for consumption by animals and people) and for cork production. The cork trees are among the best adapted plant species to sustain wildfires as their thick bark (the cork) protects the stem buds and thus most trees resprout from the crown after fire (Pausas 1997). In the understory of these forests there is a coexistence of species with different fire traits (i.e., traits to persist in fire-prone environments): a) the ability to resprout after fire and b) the ability to produce a persistent seed bank, the dormancy of which is broken by fire, and thus recruitment is fire stimulated (Bond and Van Wilgen 1996). The combination of these two binary traits (resprouting and post-fire recruitment) give the typical four fire strategies of Mediterranean-type ecosystems (Pausas 1999; Pausas et al. 2004): obligate resprouters (resprouters hereafter), obligate seeders (seeders hereafter), species with both traits (facultative species; these do not rely on any particular regeneration strategy for survival), and species without any of these fire traits (non- 
sprouters and non-seeders). In the woody flora of cork oak forests, resprouters are the dominant species but coexist with seeders and also with facultative species, although the abundance of the latter is low as a feature of the Mediterranean Basin flora (Pausas et al. 2004; Pausas and Verdú 2005). We wanted to know which factors determine the richness of the dominant post-fire strategies, obligate seeders and obligate resprouters (i.e., R-P+ and R+P- respectively, sensu Pausas et al. 2004).

It has been suggested that seeder species should perform better in most disturbed ecosystems and in drier (low productivity) conditions. Their capacity to sustain throughout recurrent disturbances is explained by the fact that they typically produce many small seeds and have an earlier reproductive age than resprouters (Herrera 1984, 1992; Keeley 1998; Verdú 2000; Pausas et al. 2004). Their seeds have a dormancy which is broken by disturbance, such as the heat of a fire, the friction when moving soil, or even by the heat of the Mediterranean sun on the soil of a vegetation gap (e.g., after clearing). Furthermore, seeders tend to have traits that allow them to better sustain throughout dry periods, such as very small and thick leaves, summer semi-deciduous leaves, a higher leaf mass area ratio, or a higher water-use efficiency (Paula and Pausas 2006; Pratt et al. 2007). Thus, even the species with different fire traits may coexist, although the number of species may differ in different parts of the landscape with different disturbance regimes and water availability conditions (Malanson and O'Leary 1982; Le Maitre and Midgley 1992; Zedler 1995). Previous works in different Mediterranean climate regions worldwide associated the seeders with the drier parts of the landscape (Keeley 1986; Benwell 1998; Ojeda, 1998; Pausas 1999; Meentemeyer et al. 2001; Clarke and Knox 2002) and whit disturbed sites (Bond and Van Wilgen 1996; Ojeda et al. 1996; Pausas et al. 2004; Lloret et al. 2005; Pausas and Bradstock 2007).

A current challenge in ecology is understanding how patterns and processes vary with scale (Chapin \& Körner 1995; Derocq 2002). Many environmental gradients influence vegetation patterns at different spatial scales and plants may detect these gradients more or less sharply (Day et al 1988; Rosenzweig 1995; Ojeda 1998). Therefore it is important to know whether the processes that determine community structure at different scales are similar, and if not, how and under what circumstances the dominant processes change with scale of observation (Reed et al. 1993). Thus, the effects of disturbance and water availability on the post-fire strategies in Mediterranean climate regions are well known for the different spatial scales of analysis which have contextualized these works (from the patch to the landscape scale). Nevertheless little is known about the effects that the scale of analysis used (local or large scale) in a specific area has on these factors (disturbance and water availability) and, therefore, on the segregation of the dominant post-fire strategies.

Specifically, we predicted that species with regeneration through sexual reproduction, i.e., propogule (seeders) should appear most frequently in the drier and most disturbed parts of the landscape regardless of the scale of analysis used. In other words, our aim was to determine whether the scale of analysis influenced the factors which determine richness among plants with dominant post-fire strategies (obligate seeders and obligate resprouters) in Mediterranean-type ecosystems. Facultative species, due to their presence, were also considered in the study.

We tested this question in cork oak (Quercus suber) forests of the southern Iberian Peninsula, where there are strong moisture gradients and disturbance is common; Coca (2007) demonstrated that vegetation in this cork oak forest is subject to a predominant climatic gradient of moisture related to altitude (fog and rainfall), and to another secondary gradient related to disturbance (clearing by heavy machinery and fire) and to hydric stress associated with aspect (south-facing and north-facing slopes).

In this study, the moisture regime was evaluated at the local scale by aspect (north-facing slopes are moister than south-facing slopes), and at the larger scale by altitude (lower altitudes are warmer and receive less rainfall, and thus are drier than higher altitudes). The disturbance regime was also evaluated at the local scale using available recent historical information on fires and clearing by heavy machinery. 


\section{Materials and methods}

\section{Study area}

We studied the cork oak forests in Los Alcornocales Natural Park $\left(36^{\circ} 03^{\prime}-36^{\circ} 45^{\prime} \mathrm{N}\right.$ and $5^{\circ} 20^{\prime}$ $\left.5^{\circ} 45^{\prime} \mathrm{W} ; 167,767 \mathrm{ha}\right)$, located just north of the Straits of Gibraltar, in the extreme west of the Betic Cordillera (southern Spain). This cork oak forest is the most widely represented community in the Natural Park. With an area greater than 80,000 ha, it is the largest cork oak forest on the Iberian Peninsula, and it is probably the best conserved cork oak forest in the western Mediterranean Basin (Aronson et al. 2009). The landscape is defined by a series of mostly north/south-oriented mountain ranges with a maximum altitude of $1092 \mathrm{~m}$. The soils originate from Oligocene-Miocene sandstones and are acidic and nutrient poor.

The temperatures are characterised by their gentleness and regularity: annual average: $15.7^{\circ} \mathrm{C}$; average maximum: $34.3^{\circ} \mathrm{C}$; average minimum: $2.78^{\circ} \mathrm{C}$ (CMA 2004). The total annual precipitation is distributed from September to May and ranges from 700-2000 mm depending on the altitude. In the study area, altitude and rainfall are positively correlated (Coca and Pausas 2009). Furthermore, fog is frequent in the upper part of the study area, even in summer, softening the annual dry period. Thus, the relationship between altitude and water availability to plants is very strong and clear (Coca 2001).

A synopsis of human activities and natural disturbances in this cork oak forest may be found in Coca (2007), from among which we can mention: harvesting cork from Quercus suber every nine years; slashing shrubs from beneath the tree canopy; clearing the woody understory with heavy machinery; keeping livestock, mainly cattle, goats and swine; game hunting, mostly deer, which started in the 1970s; and the collection of firewood from pruning. There are also consequences for the vegetation from frequent forest fires, both accidental and intentional, during the summer.

\section{Sampling}

The sampling methods used followed those of Coca (2007) and Coca and Pausas (2009), with some modifications. To sample a broad spectrum of cork oak forests, fourteen representative land tenure types were selected. In each land tenure, we established several sites at different altitudes (a total of 31 sites of altitude ranging from 150 to $650 \mathrm{~m}$ ), and in each site we select three (rarely two or four) plots of $20 \times 20 \mathrm{~m}$ with different aspects (north and south facing) and different recent disturbance histories (disturbed/undisturbed), giving a total of 94 plots. The disturbed sites were considered as those which were burnt or cleared (usually with the use of machinery, affecting the soil) at least once since 1960 (the earliest year with reliable disturbance history information). We recorded both woody plant species richness and the richness of species presenting the different post-disturbance regeneration traits (obligate resprouters, obligate seeders and facultative species) within three plots of $5 \times 5 \mathrm{~m}$ which were randomly selected from each of the $20 \times 20 \mathrm{~m}$ plots. The regeneration traits for each species (Table 1) were assigned on the basis of field experience and from a trait database (Paula et al. 2009).

\section{Data analysis}

For each regenerative type (resprouter, seeder and facultative species), we tested the relationship between the number of species (species richness) and the predictors, using a generalised linear mixed model (GLMM) assuming a Poisson error distribution and a logarithm link function (McCullagh and Nelder 1989; Faraway 2006; Zuur et al. 2007). The fixed predictors considered were altitude, aspect (north/south) and disturbance (fire and clearing by heavy machinery; yes/no) and the random predictor was the factor of site. These predictors were introduced using a stepwise procedure to obtain the most parsimonious model. Interactions were also tested. When the random component did not have significant effect for some regenerative type, the relationship betwen species richness and the predictors was tested using a generalised 
linear model (GLM) with the same assumptions as in the GLMM. The significance of the model was tested by analysis of the deviance using the $\chi^{2}$ criteria. The proportion of seeders versus total species was also tested in a similar manner, but using a binomial error distribution and a logit link function in the GLMM and GLM. The results are graphically displayed by the fit of the models with the standard errors of the fits. All analysis was performed in R (R Development Core Team 2009).

\section{Results}

The total number of woody species in the sampled plots ranged from 4 to 25 species (in $75 \mathrm{~m}^{2}$ ); the seeders were either absent or represented up to $45 \%$ of the total species (mean $=18 \%$ ); the facultative species were also either absent or accounted up to $28.6 \%$ of the species (mean $=7 \%$ ). All of the predictors were independent of each other; that is, disturbance was neither related to aspect $\left(\chi^{2}=0.514, \mathrm{p}=0.47\right)$ nor to altitude $(\mathrm{t}=-0.15, \mathrm{p}=0.88)$, and aspect was not related to altitude $(\mathrm{t}=0.94, \mathrm{p}=0.35)$.

The factor of site accounted for a significant proportion of the remaining variability for facultative species but not for seeder and resprouter species richness or for the proportion of seeders (Table 2). Indeed, for facultative species, the factor of site was the most important variable, suggesting that other factors related to the spatial distribution of the sites which had not been considered may be very important for these species.

Altitude was strongly and negatively related to resprouter and seeder richness (Table 3, Figs. 1 and 2). There were very few facultative species (up to three per site) and their number was also negatively related to altitude but only on north-facing slopes. (Table 3). That is, cork oak forests located at low altitudes (in warmer and drier conditions) are richer in species than those located at high altitudes, and these changes in richness were due mainly to both resprouters and seeders.

However, at a more local scale, aspect and disturbance played a fundamental role in explaining the different richness patterns between regeneration strategies. Resprouting species were more abundant at lower altitudes and in undisturbed sites, independently of the aspect (Fig. 1). Seeders were also found at lower altitudes, but more often on south-facing slopes, especially in disturbed sites (Fig. 2). North-facing undisturbed slopes were the poorest in seeder species. The proportion of species that were seeders was not related to altitude, but was related to disturbance and aspect (Table 3). Seeders made up a larger proportion of the species on south-facing slopes, especially on those that were disturbed (Fig. 3).

\section{Discussion}

The results suggest that woody species richness is higher at low altitudes, at the warmer and drier end of the gradient, since both resprouters and seeders had their maximum richness here. At this scale (altitudinal gradient), both resprouters and seeders showed similar patterns; indeed, the proportion of seeders was not related to altitude (which is a moisture gradient).

In the cork oak forest, Coca (2007) relates the decrease in species diversity due to the extensive cover of Pteridium aquilinum (up to $90 \%$ of the total cover; mean $=11 \%$ ) as a consequence of the increasing moisture gradient associated with altitude. This bracken is considered to be one of the most successful invasive plant species and is common all over the world, except in very cold or dry conditions (Taylor 1990). Thus, in the study area, at higher altitudes the summer drought is softened due to higher rainfall and frequent fog throughout the year, allowing the spread of this fern. Stands dominated by Pteridium aquilinum are usually floristically poor (Rymer 1976; Pakeman and Marrs 1992).

For the facultative species, the spatial distribution of the sites may be very important. Four out of the five facultative species belonged to the Fabaceae family (Table 1). Woody legumes do not adapt as well as other species of Mediterranean scrub to the extreme conditions of recurrent drought in the Mediterranean climate of southern Spain (Herrera 1984). Therefore, it was suggested that these species depend on the existence of microhabitat sites with low moisture fluctuations (e.g., 
rooting under rocks). Moreover, the fifth species with this strategy (Erica australis) is associated with more acidic and nutrient-poor soils (Marañón et al. 1999; Coca 2001, 2007). The presence or absence of these habitats within the study plots explain the importance of the factor of site.

The dominance of seeders has previously been reported at both the drier (Keeley 1986; Meentemeller et al. 2001) and the moister (Ojeda 1998; Benwell 1998) ends of moisture gradients. However, at the local scale, seeders are certainly associated with the driest parts of the landscape (south-facing slopes) and in disturbed sites (Fig. 3), while resprouters are more abundant in undisturbed sites (independently of the aspect). Thus, our results are scale dependent in such a way that at the large scale (altitudinal gradient) there are no differences between resprouters and seeders, but differences are found at the local scale (aspect and disturbance). The association of seeders with the drier parts of the landscape is consistent with the recent observations that seeders have morphological and physiological traits which confer a high tolerance to drought (Paula and Pausas 2006; Pratt et al. 2007; Suara-Mas and Lloret 2007).

The results also emphasise the role of seeders as disturbance-dependent (gap) recruiters (Keeley 1998), that is, they mainly recruit after a disturbance, thanks to the persistent seed bank they produce and the capacity of their germination to be stimulated by fire products, mainly heat, but also smoke or charred wood (Moreira et al. 2010), or by mechanical scarification of seeds due to strong soil disturbance (Baeza and Vallejo 2006). Although recruitment may be stimulated after other disturbances caused by humans (e.g., by the increased heat from the summer sun after slashing shrubs (Lloret and Vilà 1997), this stimulation may not be as great as after a fire or after clearing by heavy machinery because of the larger extent or magnitude of these disturbances, as well as the multiple and effective germination cues produced by them.

The fact that the trend observed at the local scale (higher richness of seeders in dry places) was not shown at the large scale may seem surprising. However, cork oak forests are relatively open, even in high rainfall. This may be a legacy of the long-term human exploitation of cork which maintained a low density of trees to reduce competition and thus facilitate the growth of cork, but also to the relatively high density of large herbivores that reduce oak regeneration. Furthermore, the crown structure of the cork oak is very open, with separated branches and a low density of leaves, thus producing a very light shade. This open forest creates a similarly appropriate environment for seeder light-demanding species at any altitude. It is at the local scale, more specifically at the drier places with high radiation, where the species richness of seeder species is enhanced. On the other hand, roughly every nine years shrubs are slashed from beneath the tree canopy to facilitate the cork harvest and eliminate combustible material (Coca 2007). These human activities prevent the effect of competitive exclusion (Grime 1979), allowing species with different morphological and physiological traits (seeders/resprouters) to coexist, including species (seeders) that would otherwise be excluded from the community.

In summary, although resprouters are the predominant post-fire plant strategy in the cork oak forests of the Los Alcornocales Natural Park, they coexist with other different post-fire strategies and the degree of coexistence is not random across the landscape. At the local scale, there is a segregation of the richness of seeders and resprouters mediated by local processes such as strong disturbance (fire and mechanical soil movement) and water availability associated with aspect. At the large scale, the moisture gradient associated with altitude does not affect segregation of the richness of plants with different strategies due to disturbances related to human activities.

\section{Acknowledgments}

The authors thank J.C. Muñoz Reinoso for helpful comments, criticisms and discussion about the manuscript. The experiments described here comply with the current laws of Spain in which the experiments were performed. 


\section{References}

Aronson J, Pereira JS, Pausas JG eds (2009) Cork oak woodlands on the edge. Island Press, Washington DC

Baeza J, Vallejo VR (2006) Ecological mechanisms involved in dormancy breakage in Ulex parviflorus seeds. Plant Ecol 183: 191-205

Benwell AS (1998) Post-fire seedling recruitment in coastal heathlands in relation to regeneration strategy and habitat. Aust J Bot 46:75-101

Chapin FS, Körner C (1995) Patterns, causes, changes and consequences of biodiversity in arctic and alpine ecosystems. In: Chapin FS, Körner C (eds) Arctic and alpine biodiversity: patterns, causes and ecosystem consequences. Springer-Verlag, Berlin, pp 313-320

Bond WJ, Van Wilgen BW (1996) Fire and plants. Chapman \& Hall, London

Clarke PJ, Knox KJE (2002) Post-fire response of shrubs in the tablelands of eastern Australia: do existing models explain habitat differences? Aust J Bot 50: 53-62

CMA (2004) Plan de Ordenación de los Recursos Naturales y Plan Rector de Uso y Gestión del Parque Natural Los Alcornocales. Consejería de Medio Ambiente, Junta de Andalucía, Sevilla

Coca M (2001) Árboles, arbustos y matas del Parque Natural Los Alcornocales. Ornitour, Cádiz

Coca M (2007) Diversity in the cork oak forests of the northern Straits of Gibraltar Region (Southern Spain). Plant Ecol 189: 87-100

Coca M, Pausas JG (2009) Regeneration traits are structuring phylogenetic diversity in cork oak (Quercus suber) woodlands. J Veg Sci 20:1009-1015

Day RT, Keddy PA, McNeill J, Carleton T (1988) Fertility and disturbance gradients: a summary model for riverine marsh vegetation. Ecology 69: 1044-1054

Derocq G (2002) Patterns of plant species and community diversity at different organization levels in a forested riparian landscape. J Veg Sci 13:91-106

Faraway JJ (2006) Extending the linear model with R : generalized linear, mixed effects and nonparametric regression models. Chapman an Hall/CRC, Boca Raton

Grime JP (1979) Plant strategies and vegetation processes. John Wiley and Son, Chichester

Herrera CM (1984) Tipos morfológicos y funcionales en plantas del matorral mediterráneo del sur de España. Studia Oecologica V:7-34

Herrera CM (1992) Historical effects and sorting processes as explanations for contemporary ecological patterns: character syndromes in Mediterranean woody plants. Am Nat 140:421446

Keeley JE (1986) Resilience of mediterranean shrub communities to fires. In: Dell B, Hopkins AJM, Lamont BB (eds) Resilience in Mediterranean-Type Ecosystems. Dr W. Junk, Dordrecht, pp 95-112

Keeley JE (1998) Coupling demography, physiology and evolution in chaparral shrubs. In: Rundel PW, Montenegro G, Jaksic FM (eds) Landscape Disturbance and Biodiversity in Mediterranean-Type Ecosystems. Springer, Berlin, pp 257-264

Le Maitre DC, Midgley JJ (1992) Plant reproductive ecology. In: Cowling RM (ed) The Ecology of Fynboss: Nutrients, Fire and Diversity. Oxford University, Oxford, pp 135-174

Lloret F, Vilà M (1997) Clearing of vegetation in Mediterranean garrigue: response after a wildfire. For Ecol Manag 93: 227-234 
Lloret F, Estevan H, Vayreda J, Terradas J (2005) Fire regenerative syndromes of forest woody species across fire and climatic gradients. Oecologia 146: 461-468

Malanson GP, O’Leary JF (1982) Post-fire regeneration strategies of Californian coastal sage shrubs. Oecologia 53: 355-358

Marañón T, Ajbilou R, Ojeda F, Arroyo J (1999) Biodiversity of woody plants in oak woodlands of southern Spain and northern Morocco. For Ecol Manag 115: 147-156

McCullagh P, Nelder JA (1989) Generalized linear models. 2nd edn. Chapman and Hall, London

Meentemeyer RK, Moody A, Franklin J (2001) Landscape-scale patterns of shrub-species abundance in California chaparral: the role of topographically mediated resource gradients. Plant Ecol 156:19-41

Moreira B, Tormo J, Estrelles E, Pausas JG (2010) Disentangling the role of heat and smoke as germination cues in Mediterranean Basin flora. Ann Bot 105:627-635

Ojeda F, Marañón T, Arroyo J (1996) Postfire regeneration of a Mediterranean heathland in Southern Spain. Int J Wildland Fire 6: 191-198

Ojeda F (1998) Biogeography of seeder and resprouter Erica species in the Cape Floristic Region - where are the resprouters? Biol J Linn Soc 63: 331-347

Pakeman RJ, Marrs RH (1992) The conservation value of bracken Pteridium aquilinum (L.) Kuhndominated communities in the UK, and an assessment of the ecological impact of bracken expansion or its removal. Biol Conserv 62:101-114

Paula S, Pausas JG (2006) Leaf traits and resprouting ability in the Mediterranean basin. Funct Ecol 20: 941-947

Paula S, Arianoutsou M, Kazanis D, Tavsanoglu C, Lloret F, Buhk C, Ojeda F, Luna B, Moreno JM, Rodrigo A, Espelta JM, Palacio S,Fernández-Santos B, Fernandes PM, Pausas JG (2009) Fire-related traits for plant species of the Mediterranean Basin. Ecology 90: 1420

Pausas JG (1997) Resprouting of Quercus suber in NE Spain after fire. J Veg Sci 8: 703-706

Pausas JG (1999) Mediterranean vegetation dynamics: modelling problems and functional types. Plant Ecol 140: 27-39

Pausas JG, Verdú M (2005) Plant persistence traits in fire-prone ecosystems of the Mediterranean Basin: A phylogenetic approach. Oikos 109: 196-202

Pausas JG, Bradstock RA (2007) Fire persistence traits of plants along a productivity and disturbance gradient in Mediterranean shrublands of SE Australia. Global Ecol Biogeogr 16: $330-340$

Pausas JG, Bradstock RA, Keith DA, Keeley JE, GCTE Fire Network (2004) Plant functional traits in relation to fire in crown-fire ecosystems. Ecology 85: 1085-1100

Pratt RB, Jacobsen AL, Golgotiu KA, Sperry JS,Ewers FW, Davis SD (2007) Life history type and water stress tolerance in nine California chaparral species (Rhamnaceae). Ecol Monogr 77: 239-253

R Development Core Team (2009) R: A language and environment for statistical computing. R Foundation for Statistical Computing, Vienna, Austria. URL http://www.R-project.org.

Reed RA, Peet R, Palmer MW, White PS (1993) Scale dependence of vegetation-environment correlations: A case study of a North Carolina piedmont woodland. J Veg Sci 4: 329-340

Rosenzweig ML (1995) Species diversity in time and space. Cambridge University Press, Cambridge, UK 
Rymer L (1976) The history and ethnobotany of bracken. Bot J Linn Soc 73:151-176

Saura-Mas S, Lloret F (2007) Leaf and Shoot Water Content and Leaf Dry Matter Content of Mediterranean Woody Species with Different Post-fire Regenerative Strategies. Ann Bot 99: $545-554$

Taylor JA (1990) The bracken problem: a global perspective. In: Taylor JA., Smith RT(eds) Bracken control and management. Australian Institute of Agricultural Science, Sydney, pp 319

Verdú M (2000) Ecological and evolutionary differences between Mediterranean seeders and resprouters. J Veg Sci 11:265-268

Zedler PH (1995) Plant Life History and Dynamic Specialization in the chaparral/coastal sage shrub flora in Southern California. In: Arroyo MTK, Zedler PH, Fox MD (eds) Ecology and biogeography of Mediterranean ecosystems in Chile, California and Australia. Springer, New York NY, pp 89-115

Zuur AF, Ieno EN, Smith GM (2007) Analysing ecological data. Springer, New York 
Table 1 Species post-fire regeneration traits considered ( $R$, resprouting ability, circles; $P$, post-fire seeding, squares). Filled symbols indicate species having the ability to regenerate post fire by means of resprouting (circles) and/or by germinating (squares); empty symbols indicate species that lack the corresponding regeneration ability. We were not sure of the regeneration strategy of some species (no symbols) because the information was not available or because there was conflicting information. These species are not considered in the analysis (Extracted from Coca and Pausas 2009).

\begin{tabular}{|c|c|c|c|c|c|}
\hline Species & $R$ & $P$ & Species & $R$ & $P$ \\
\hline Adenocarpus telonensis & & & Lavandula stoechas & O & $\mathbf{\square}$ \\
\hline Arbutus unedo & • & $\square$ & Lithodora prostrata & $\bullet$ & $\square$ \\
\hline Aristolochia baetica & & & Lonicera implexa & $\bullet$ & $\square$ \\
\hline Asparagus albus & • & 口 & Lonicera periclymenum & $\bullet$ & $\square$ \\
\hline Asparagus aphyllus & $\bullet$ & $\square$ & Myrtus communis & $\bullet$ & $\square$ \\
\hline Bupleurum foliosum & $\bullet$ & $\square$ & Nerium oleander & $\bullet$ & $\square$ \\
\hline Calicotome villosa & $\bullet$ & $\square$ & Olea europaea & $\bullet$ & $\square$ \\
\hline Calluna vulgaris & & & Osyris alba & $\bullet$ & $\square$ \\
\hline Ceratonia silicua & • & $\square$ & Phlomis purpurea & 0 & - \\
\hline Chamaerops humilis & $\bullet$ & $\square$ & Phyllirea angustifolia & $\bullet$ & $\square$ \\
\hline Cistus crispus & O & - & Phyllirea latifolia & $\bullet$ & $\square$ \\
\hline Cistus ladanifer & O & - & Pistacia lentiscus & $\bullet$ & $\square$ \\
\hline Cistus monspeliensis & 0 & - & Polygala baetica & & \\
\hline Cistus populifolius & ○ & घ & Pyrus bourgeana & $\bullet$ & $\square$ \\
\hline Cistus salvifolius & ○ & घ & Quercus canariensis & $\bullet$ & $\square$ \\
\hline Clematis flammula & $\bullet$ & $\square$ & Quercus coccifera & $\bullet$ & $\square$ \\
\hline Crataegus monogyna & $\bullet$ & $\square$ & Quercus fruticosa & $\bullet$ & $\square$ \\
\hline Cytisus baeticus & $\bullet$ & $\square$ & Quercus suber & $\bullet$ & $\square$ \\
\hline Cytisus striatus & $\bullet$ & - & Rhamnus alaternus & $\bullet$ & $\square$ \\
\hline Cytisus villosus & $\bullet$ & $\square$ & Rhamnus lycioides & $\bullet$ & $\square$ \\
\hline Daphne gnidium & $\bullet$ & $\square$ & Rosa sempervirens & $\bullet$ & $\square$ \\
\hline Daphne laureola & $\bullet$ & $\square$ & Rubus ulmifolius & $\bullet$ & $\square$ \\
\hline Drosophyllum lusitanicum & O & $\square$ & Ruscus aculeatus & $\bullet$ & $\square$ \\
\hline Erica arborea & $\bullet$ & $\square$ & Ruscus hypophillum & $\bullet$ & $\square$ \\
\hline Erica australis & $\bullet$ & - & Salix sp. & $\bullet$ & $\square$ \\
\hline Erica scoparia & $\bullet$ & $\square$ & Satureja salzmannii & ○ & - \\
\hline Erica umbelata & O & घ & Smilax aspera & $\bullet$ & $\square$ \\
\hline Genista linifolia & $\bullet$ & $\square$ & Stauracanthus boivinii & $\bullet$ & घ \\
\hline Genista monspesulana & $\bullet$ & $\square$ & Teucrium fruticans & $\bullet$ & $\square$ \\
\hline Genista triacanthos & ○ & - & Teucrium scorodonia & $\bullet$ & $\square$ \\
\hline Genista tridens & $\bullet$ & $\square$ & Thymelaea villosa & $\bullet$ & $\square$ \\
\hline Genista tridentata & $\bullet$ & - & Tuberaria lignosa & & \\
\hline Halimium halimifolium & $\circ$ & - & Ulex borgiae & $\bullet$ & घ \\
\hline Hedera helix & $\bullet$ & $\square$ & Viburnun tinus & $\bullet$ & $\square$ \\
\hline Laurus nobilis & $\bullet$ & $\square$ & & & \\
\hline
\end{tabular}


Table 2 Importance of random component (factor of site) for species richness of the different regeneration types. The estimates were made based on the loss of variance of this factor in model (GLMM) with only random component compared to parsimonious model for species richness of each regeneration type.

\begin{tabular}{|c|c|c|c|}
\hline & \multicolumn{2}{|c|}{ Variance of random component (Site) } & \multirow[b]{2}{*}{$\begin{array}{c}\text { Site loss variance } \\
(\%)\end{array}$} \\
\hline & $\begin{array}{l}\text { Model with only } \\
\text { random component }\end{array}$ & Parsimonious model & \\
\hline $\begin{array}{l}\text { Richness of obligate } \\
\text { seeder species (R-P+) }\end{array}$ & 0.20701 & $<0.0000001$ & 100 \\
\hline $\begin{array}{l}\text { Richness of obligate } \\
\text { resprouter species }(\mathrm{R}+\mathrm{P}-)\end{array}$ & 0.07104 & 0.021409 & 70 \\
\hline $\begin{array}{l}\text { Richness of facultative } \\
\text { species }(R+P+)\end{array}$ & 0.48829 & 0.29692 & 39 \\
\hline $\begin{array}{l}\text { Proportion of obligate } \\
\text { seeder species (R-P+) }\end{array}$ & 0.23344 & 0.0051421 & 98 \\
\hline
\end{tabular}


Table 3 Summary of the GLM stepwise statistics for species richness of the regeneration types obligate seeder (a), obligate resprouters (b) and for the proportion of seeders in relation to the total species (c). For richness of facultative species (d) showing the results of the GLMM.

\begin{tabular}{|c|c|c|c|c|c|c|}
\hline Anova & $\mathrm{DF}$ & Deviance & $\begin{array}{l}\text { Residual } \\
\text { DF }\end{array}$ & $\begin{array}{l}\text { Residual } \\
\text { deviance }\end{array}$ & $p$ & $\begin{array}{c}\text { Explained } \\
\text { deviance }\end{array}$ \\
\hline \multicolumn{7}{|c|}{ a) Richness of obligate seeder species (R-P+) } \\
\hline Null & & & 93 & 116.253 & & \\
\hline +Altitude & 1 & 15.871 & 92 & 100.402 & 0.00006 & 13.63 \\
\hline +Disturbance & 1 & 10.763 & 91 & 89.639 & 0.00103 & 22.89 \\
\hline+ Aspect & 1 & 22.908 & 90 & 66.731 & $<0.00001$ & 42.60 \\
\hline \multicolumn{7}{|c|}{ B) Richness of obligate resprouter species $(R+P-)$} \\
\hline Null & & & 93 & 146.980 & & \\
\hline+ Altitude & 1 & 36.607 & 92 & 110.373 & $<0.00001$ & 24.89 \\
\hline +Disturbance & 1 & 15.520 & 91 & 94.853 & 0.00008 & 35.47 \\
\hline+ Aspect & 1 & 0.027 & 90 & 94.826 & 0.8684 & 35.48 \\
\hline \multicolumn{7}{|c|}{ x) Proportion of obligate seeder species $(R-P+)$} \\
\hline Null & & & 93 & 109.515 & & \\
\hline+ Altitude & 1 & 1.2701 & 92 & 108.245 & 0.2597 & 1.16 \\
\hline +Disturbance & 1 & 17.8752 & 91 & 90.370 & 0.00002 & 17.48 \\
\hline+ Aspect & 1 & 16.8282 & 90 & 73.542 & 0.00004 & 32.85 \\
\hline Coefficients & & & Estimate & S.E & $\mathrm{Z}$ & $\operatorname{Pr}(>|z|)$ \\
\hline \multicolumn{7}{|c|}{ a) Richness of obligate seeder species $(R-P+)$} \\
\hline Intercept & & & 1.3136 & 0.2129 & 6.169 & $<0.00001$ \\
\hline Altitude & & & -0.0027 & 0.0006 & -4.655 & $<0.00001$ \\
\hline Disturbance & & & 0.3766 & 0.1387 & 2.716 & 0.00661 \\
\hline Aspect & & & 0.6627 & 0.1413 & 4.691 & $<0.00001$ \\
\hline \multicolumn{7}{|c|}{ b) Richness of obligate resprouter species $(R+P-)$} \\
\hline Intercept & & & 2.9601 & 0.0936 & 31.618 & $<0.00001$ \\
\hline Altitude & & & -0.0015 & 0.0003 & -5.928 & $<0.00001$ \\
\hline Disturbance & & & -0.2914 & 0.0759 & -3.842 & 0.00012 \\
\hline \multicolumn{7}{|c|}{ S) Richness of facultative species $(R+P+)$} \\
\hline Intercept & & & 0.75769 & 0.45649 & 1.660 & 0.0970 \\
\hline Altitude: Nortl & ing $s$ & & -0.00307 & 0.00140 & -2.19 & 0.0285 \\
\hline Deviance & & & 96.59 & & & \\
\hline
\end{tabular}




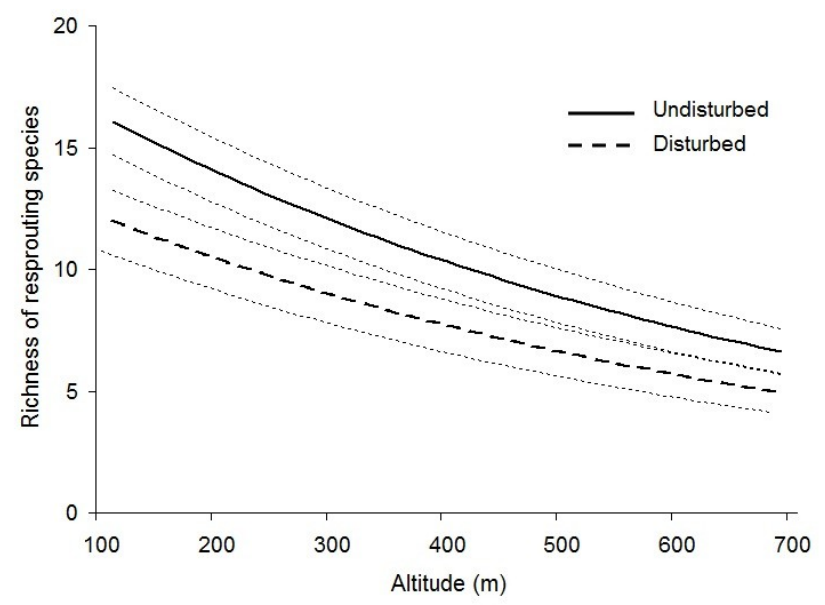

Fig. 1 Richness of obligate resprouting species (R+P-) to altitude $(\mathrm{m})$ in undisturbed and disturbed sites by the fit of GLM (Table 3 ). Dotted lines indicate 95\% confidence limits 

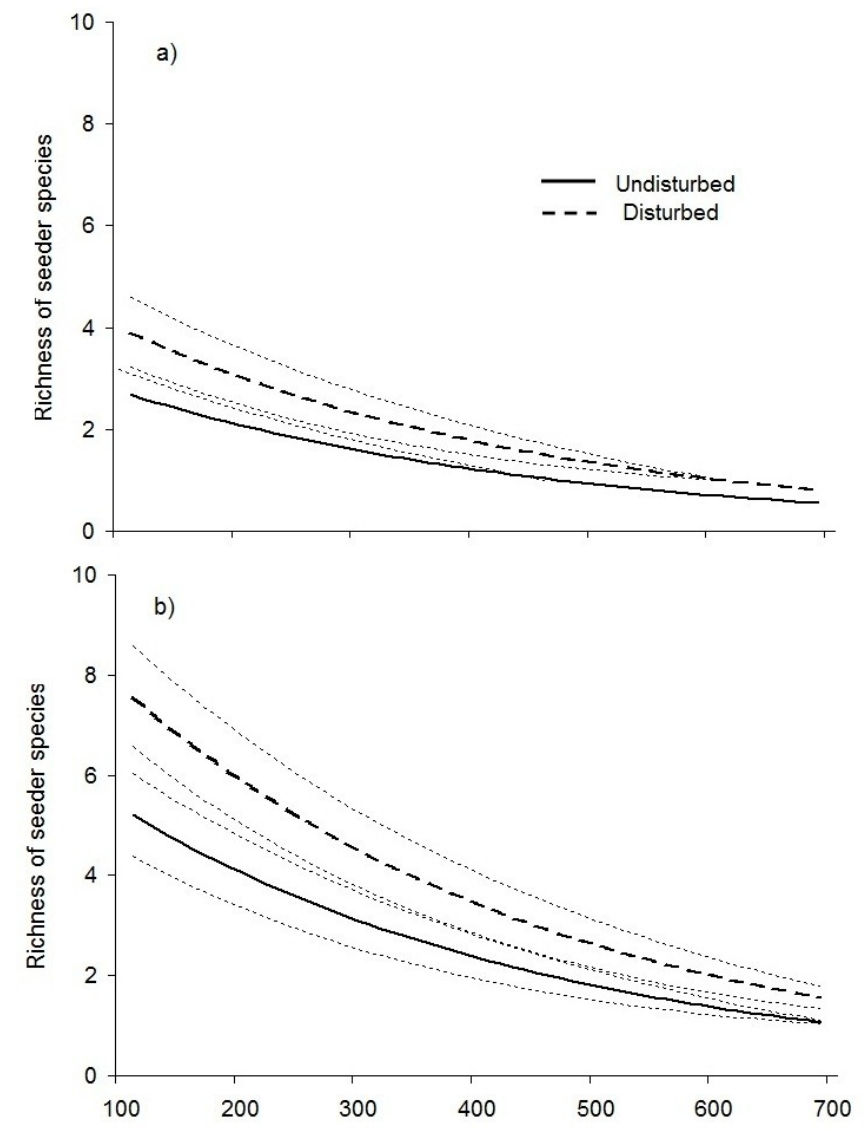

Fig. 2 Richness of obligate seeder species (R-P+) to altitude (m) on a) north-facing and b) south-facing slopes in undisturbed and disturbed sites by the fit of GLM (Table 3). Dotted lines indicate $95 \%$ confidence limits

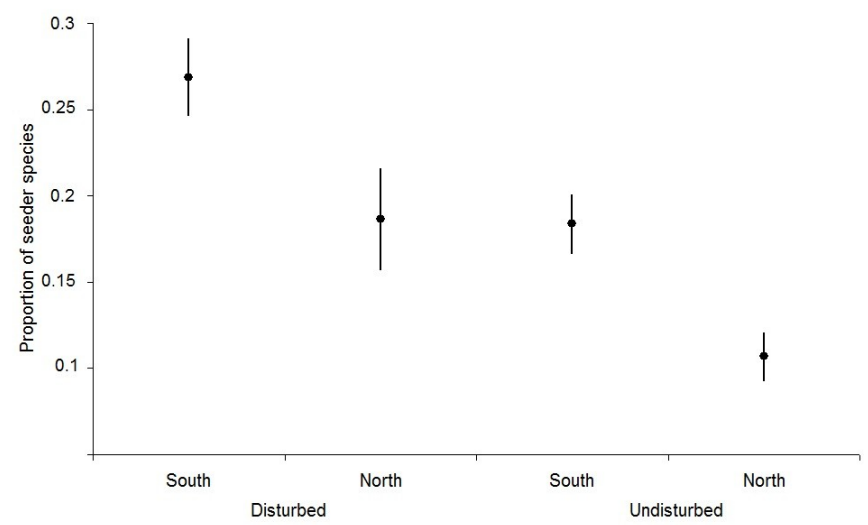

Fig. 3 Proportion of obligate seeder species (R-P+; mean \pm s.e.) in disturbed and undisturbed sites on south-facing and north-facing slopes 